\title{
Kinetic Analyses of the Formation of Solid Solution in the ZnS-CdS System.*
}

\author{
Michiko Yonemura** and Yoshihide Kotera***
}

\begin{abstract}
The formation of solid solution in the ZnS-CdS system, one of the simplest reaction which involves two or more phases, has been studied by X-ray diffraction and by the observation of ZnS or CdS phosphor in some stages of the solid solution formation.

Values of activation energy obtained from the height decrease of diffraction lines $\mathrm{ZnS}$ (102) are 35 $\mathrm{kcal} / \mathrm{mol}$ for $\mathrm{ZnS}: \mathrm{CdS}=1: 1$, and $41 \mathrm{kcal} / \mathrm{mol}$ for $7: 3$. The formation process was observed by using the phosphor as one of the starting materials. It was assumed that cadmium sulfide sublimates on the first stage of solid solution formation especially when cadmium sulfide is a form of fine powder. The presence of cadmium sulfide on the outer surface of zinc sulfide was observed by EPMA, these results supporting the above assumption. Thereafter the mutual diffusion proceeded to form solid solution. The result of emission measurement coincided with those by EPMA.
\end{abstract}

(Received October 15, 1983)

\section{Introduction}

In the previous work ${ }^{1)}$ it was found that the solid solution between $\mathrm{NaCl}$ and $\mathrm{KCl}$ is formed at $300-400^{\circ} \mathrm{C}$ and the activation energy for this formation is estimated to be $48 \mathrm{kcal} / \mathrm{mol}$. It was also found that the formation of solid solution between $\mathrm{CaO}$ and $\mathrm{SrO}$ proceeded between $1050^{\circ} \mathrm{C}$ and $1400^{\circ} \mathrm{C}$ with the activation energy of about $60 \mathrm{kcal} / \mathrm{mol}$. In these cases other phenomena seem to occur than the mutual diffusion, especially in an early stage of formation. Meanwhile it was found2) that the solid solution of $\mathrm{CaO}-\mathrm{SrO}$ system has better anti-weathering property than calcium oxide.

In this paper it was reported that the solid solution of $\mathrm{ZnS}-\mathrm{CdS}$ system is formed at $800-900^{\circ} \mathrm{C}$, the process being discussed briefly.

\section{Experimental}

Starting Materials: Luminescent pure zinc sulfide and cadmium sulfide are used as starting materials, being obtained from a factory of luminescent materials. Their crystal structures were cubic forms. By the heat-treatment at $1100^{\circ} \mathrm{C}$ for 2 hrs. zinc sulfide transformed to hexagonal structure, while cadmium sulfide did by that at $750^{\circ} \mathrm{C}$ for 40 mins. When the phosphors were used as starting materials, they were prepared as follows. Zinc sulfide was mixed with silver salt and sodium chloride solutions, then, after drying, the mixture of zinc sulfide, silver salt and sodium chloride was fired in air at $1100^{\circ} \mathrm{C}$ for $2 \mathrm{hrs}$.. The amount of silver was $10^{-2} \mathrm{~mol} \%$ of zinc sulfide. Almost the same procedure was applied to cadmium sulfide, except that the firing temperature was $800^{\circ} \mathrm{C}$.

* 昭和55年 5 月本協会春季大会にて発表, 昭和58年10月15日受理

** National Chemical Laboratory for Industry; Yatabe, Tsukuba-gun, Ibaraki 305 Japan.

*** Toyohashi University of Technology; Tempaku, Toyohashi-shi 440 Japan. 
$X$-ray Diffraction Analysis: The formation process of solid solution was observed by X-ray diffraction method for the samples which were obtained by heat-treatment of the mixtures of starting materials under various conditions. X-ray apparatus was operated at $30-40 \mathrm{KV}$ and $50-80 \mathrm{~mA}$, the anti-cathode being copper. The height change of X-ray diffraction line (102) was observed, and the rate of solid solution formation was determined from this change by the procedure described in previous report ${ }^{11}$.

Electron Probe Microanalysis: The process of solid solution formation was observed also by EPMA for the same samples as were used for X-ray diffraction analysis. The apparatus was operated at $10-20 \mathrm{KV}$ and $0.1-10 \mathrm{nA}$.

Measurement of Emission of Phosphors: When the phosphors were used as starting materials, the shift of peak wavelength of emission spectra was observed with the progress of solid solution formation. The emission spectra were measured under ultraviolet excitation by fluorescent spectrophotometer, its details being described elsewhere.

\section{Experimental Results}

Fig. 1 shows the change of $\mathrm{X}$-ray diffraction pattern with heating the mixture of starting materials, the upper series being for cubic form and the lower for hexagonal ones, respectively. The rate of solid solution formation was higher in the case of cubic form than that of hexagonal ones. That is, when started from cubic sulfides, the solid solution was formed by heating at $750^{\circ} \mathrm{C}$ for 40 mins., while about $35 \%$ of zinc sulfide remained by heating under the same conditions when both sulfides were hexagonal forms. The heating of the cubic sulfides at $850^{\circ} \mathrm{C}$ for 20 mins. resulted in the formation of well-crystallized solid solution, while in the case of the hexagonal sulfides it took 50 mins. to observe the formation of the solid solution, its diffraction lines being broad.

Fig. 2 shows the first-order plot of conversion of hexagonal zinc sulfide to the solid solution between zinc and cadmium sulfides. The numbers in the coordinate mean the common logarithm of percentage of residual amount against starting one of zinc sulfide, these amount being estimated from the heights of diffraction lines (102). Fig. 3 shows the Arrhenius plot for the formation of the solid solution where values " $\mathrm{k}$ " were obtained from Fig. 2. Values of activation energy thus obtained are $35 \mathrm{kcal} / \mathrm{mol}$ for $\mathrm{ZnS}: \mathrm{CdS}=1: 1$, and $41 \mathrm{kcal} / \mathrm{mol}$ for $7: 3$.

The results of EPMA are shown in Photos. 1-6 and Figs. 4-6. From these results it was ascertained that the layer of cadmium sulfide covers zinc sulfide crystals on the beginning of heating when cadmium sulfide used was powder.

Fig. 7 and Table 1 show the results of measurement of emission from phosphors used as
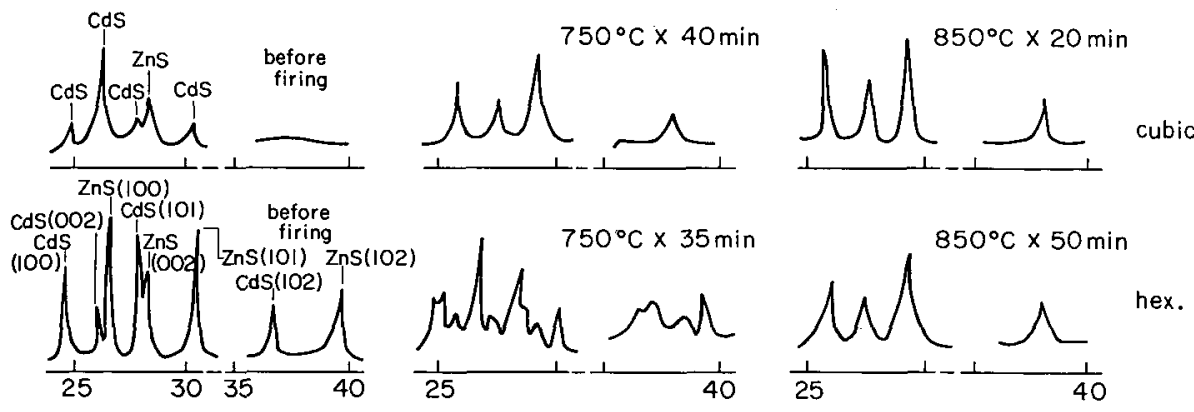

Fig. 1 Change of X-ray diffraction patterns of $\mathrm{ZnS}$-CdS system during the formation of solid solution. 


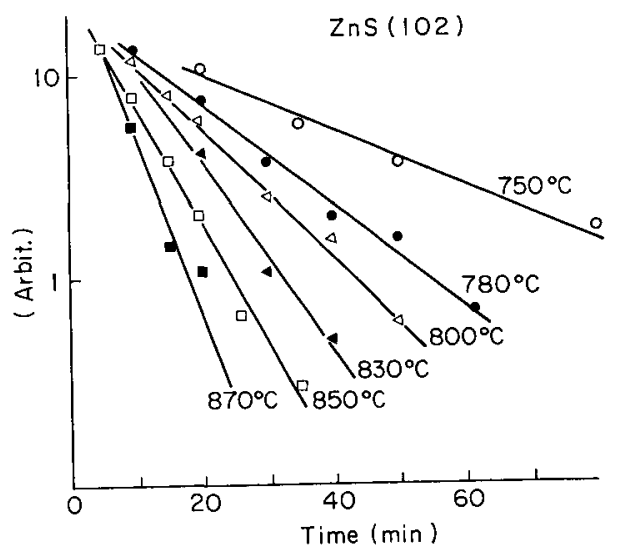

Fig. 2 First-order plot of conversion of hexagonal zinc sulfide to the solid solution.

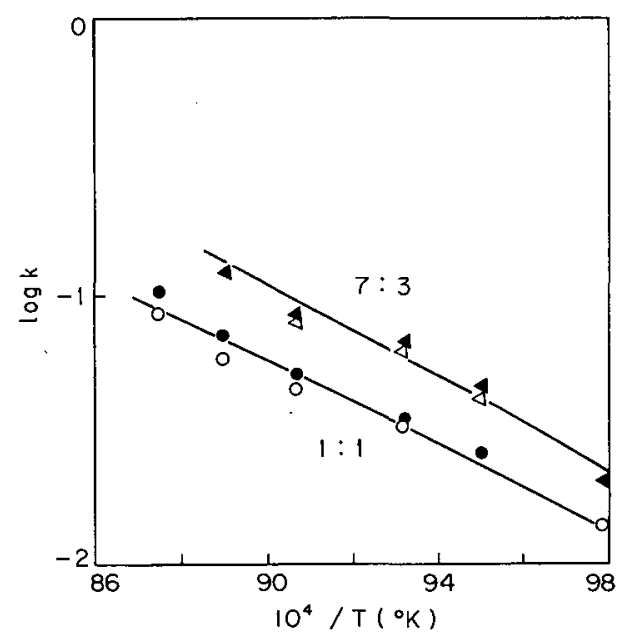

Fig. 3 Arrhenius plot for the formation of $(\mathrm{Zn}, \mathrm{Cd}) \mathrm{S}$ solid solution.

Table 1 The change of peak values of emission spectra during the formation of solid solution.

\begin{tabular}{c|c|c|c|c|c}
\hline ZnS & CdS & Before firing & $10 \mathrm{~min}$. & $30 \mathrm{~min}$. & $50 \mathrm{~min}$. \\
\hline Phospher & Powder & 440 & 635 & 615 & 605 \\
Powder & Phosphor & 700 & 530 & 560 & 565 \\
Phosphor & Phosphor & $440+700$ & 610 & 590 & 585 \\
\hline
\end{tabular}

starting materials. Fig. 7 shows the change of spectral distribution of emission from zinc sulfide phosphor which was mixed with cadmium sulfide powder, the mixture being heated at $850^{\circ} \mathrm{C}$ or higher temperature (those curves were plotted by dotted lines) for varying time. The curve denoted by $1100 \times 20$, which means the firing at $1100^{\circ} \mathrm{C}$ for 20 minutes, corresponds to the emission curve of $\left(\mathrm{Zn}_{0.5}, \mathrm{Cd}_{0.5}\right) \mathrm{S}: \mathrm{Ag}$. Peak wavelength changed with the heating time from $440 \mathrm{~nm}$ suddenly to $650 \mathrm{~nm}$, then moved to the short wavelength slowly. Such results are shown in Table 1 and the shift of peak wavelength is observed with the heating time.

\section{Discussion}

Hedvall ${ }^{3)}$ proposed that the reaction in the solid state would be divided into two groups, one being the reaction which starts from one phase, and other from two or more phases. In the latter reactions the reactions between two solids are very important from the industrial standpoint, however they are so complex, that it is difficult to elucidate their reaction mechanism.

The simplest one of the reactions which start from two or more phases would be the formation of solid solution and in the previous report ${ }^{1)}$ the processes of this formation in the $\mathrm{NaCl}-\mathrm{KCl}$ and $\mathrm{CaO}-\mathrm{SrO}$ systems have been analysed by $\mathrm{X}$-ray diffraction method. In the $\mathrm{NaCl}-\mathrm{KCl}$ system the formation proceeds in two phases during all stages of the reaction. The rate is so high that it was difficult to analyse the kinetics of the respective reaction. The activation energy of overall reaction of the formation of solid solution is estimated to be $48 \mathrm{kcal} / \mathrm{mol}$ for the product of $1: 1$ molar ratio, and a little higher for $0.65: 0.35$ product. Meanwhile, in the system of $\mathrm{CaO}-\mathrm{SrO}$ the formation proceeds in two or more phases, and it was possible to determine the value of the activation energy from the decrease of the amount of strontium oxide. The value thus obtained by means of high 
temperature X-ray diffractometry was estimated to be $61 \mathrm{kcal} / \mathrm{mol}$. From the experimental results of this research, it was clarified that the formation of solid solution proceeded by the mutual diffusion of the cations. However, the rate of formation depends on the characteristics of starting reactants as well as on the condition of the reaction.

It was published ${ }^{4)}$ in the case of solid solution of $\mathrm{ZnS}-\mathrm{CdS}$ system that this solid solution obeys to Vegard's law, this fact being ascertained by the relation between lattice constant and composition. In Fig. 1 it was found that the decrease of height of zinc sulfide diffraction lines as well as the distortion of line profile of cadmium sulfide diffraction lines occurs in the process of formation of these solid solutions. As it is possible to assume that the amount of product would be propotrional to the decrease of that of starting material, the rate constant " $k$ " was calculated from Fig. 2. From Fig. 2 it is confirmed that the formation of these solid solutions proceeded according to the first-order equation. Same result was obtained in the case of CaO-SrO system ${ }^{1)}$. From the Arrhenius plot shown in Fig. 3 it is possible to estimate the activation energy for the formation of this solid solution to be $35 \mathrm{kcal} / \mathrm{mol}$ or $41 \mathrm{kcal} / \mathrm{mol}$. These values are a littel smaller than $\mathrm{NaCl}-\mathrm{KCl}$ or $\mathrm{CaO}-\mathrm{SrO}$ system. In Fig. 3 open circles are obtained from the decrease of zinc sulfide diffraction line (101), while black points obtained from diffraction line (102), and they coincide well each other.

It is possible to clarify the formation process in detail by using the phosphor as one of the starting materials. As seen in Photos. 1-6, zinc sulfide crystal grows up during phosphor preparation ${ }^{53}$ and its diameter is about $10 \mu$, while the diameter of cadmium sulfide phosphor is about $20 \mu$. From Fig. 4 and Photos. 1-3 it is ascertained that cadmium sulfide covers the outer surface of zinc sulfide phosphors in the early stage of solid solution formation and cadmium diffuses into phosphor crystal with the lapse of time. On the contrary such a process does not occur in the case of mixture of cadmium sulfide phosphor and zinc sulfide powder as shown in Fig. 5 and Photos. 4-6. In this case zinc and cadmium diffuse mutually to form solid solution. In the case of mixture of two kinds of phosphors the result shown in Fig. 6 is almost the same as the latter. The phenomenon in which cadmium sulfide covers the surface of zinc sulfide crystal would be initiated by the sublimation of

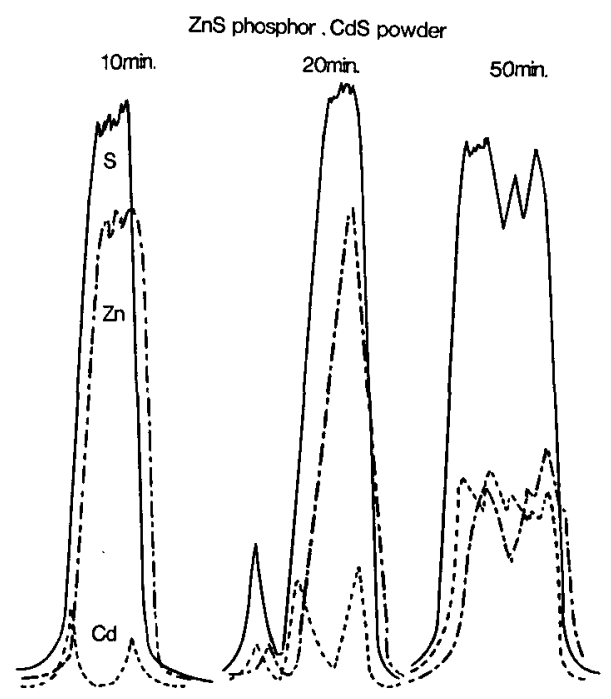

Fig. 4 Line analysis of $\mathrm{ZnS}$ crystal. The crystal was mixed with $\mathrm{CdS}$ powder and the mixture was heated at $850^{\circ} \mathrm{C}$ for 10,20 and $50 \mathrm{~min}$..

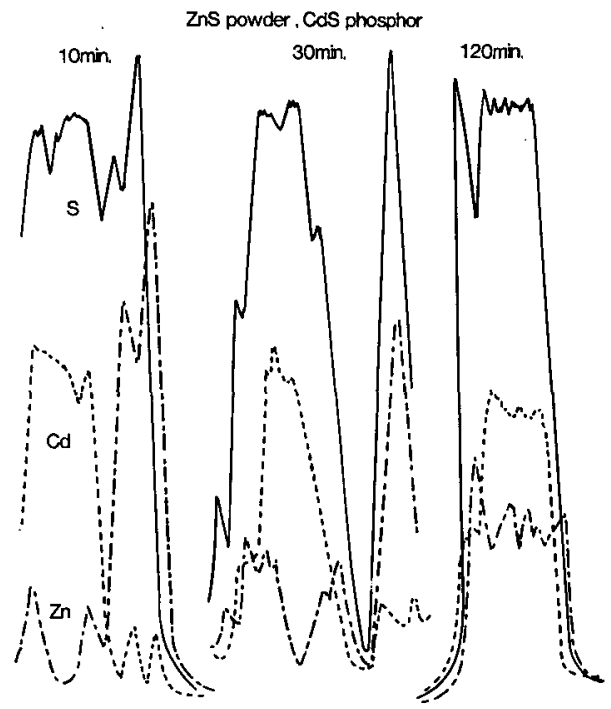

Fig. 5 Line analysis of CdS crystal. The crystal was mixed with $\mathrm{ZnS}$ powder and the mixture was heated at $850^{\circ} \mathrm{C}$ for 10,30 and $120 \mathrm{~min}$.. 


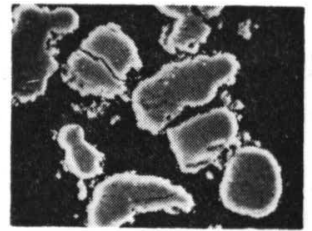

Secondary Electron Image

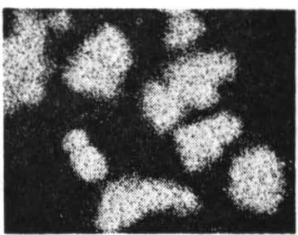

$\mathrm{ZnL} \alpha$

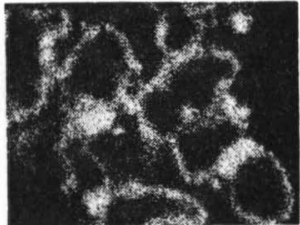

$\operatorname{CdL} \alpha$

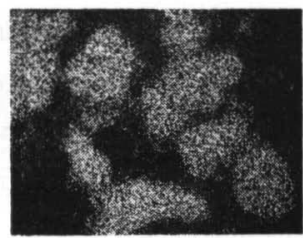

$\mathrm{SK} \alpha$

Photo. 1

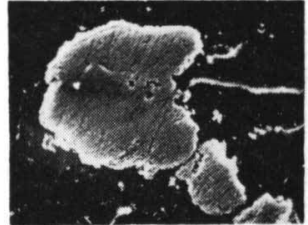

Secondary Electron Image

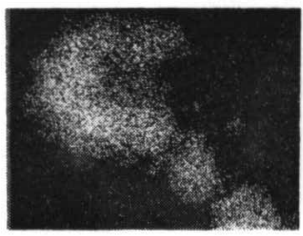

$\mathrm{ZnL} \alpha$

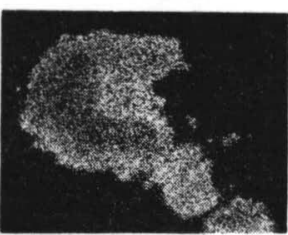

$\mathrm{CdL} \alpha$

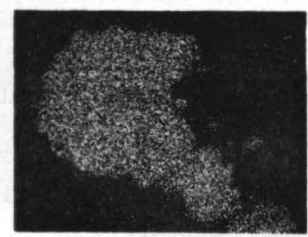

$\mathrm{SK} \alpha$

Photo. 3

ZnS phosphor, CdS phosphor

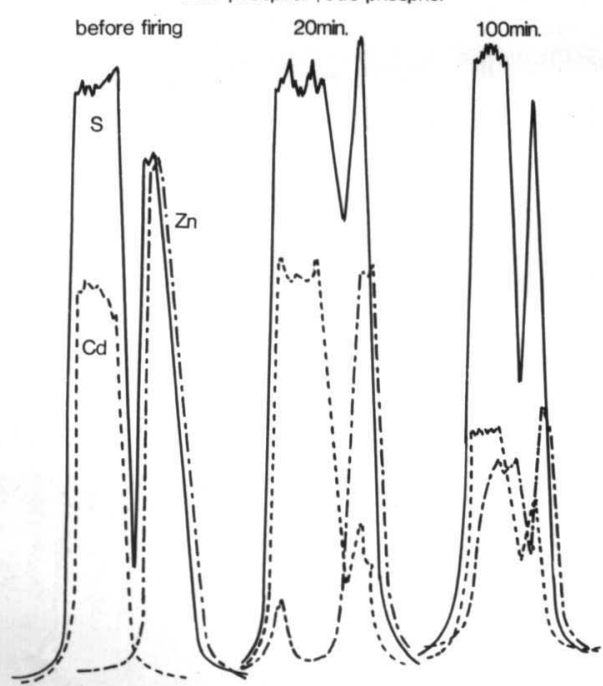

Fig. 6 Line analysis of $\mathrm{ZnS}$ and CdS crystals. Their mixture was heated at $850^{\circ} \mathrm{C}$ for 20 and $100 \mathrm{~min}$.

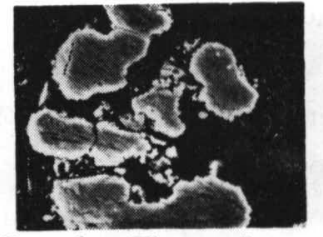

Secondary Electron Image

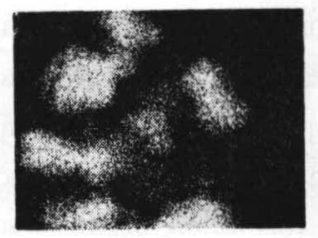

$\mathrm{ZnL} \alpha$

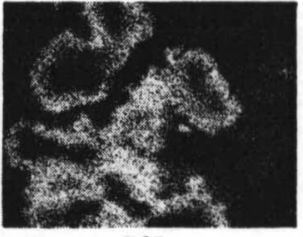

$\mathrm{CdL} \alpha$

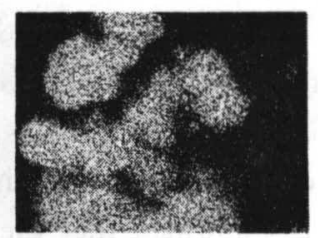

$\mathrm{SK} \alpha$

Photo. 2

Photo. 1-3. EPMA Photograph.

$\mathrm{ZnS}$ crystal and CdS powder.

1 は $850^{\circ} \mathrm{C} 10 \mathrm{~min}$.

2 は $850^{\circ} \mathrm{C} 20 \mathrm{~min}$.

3 は $850^{\circ} \mathrm{C} 50 \mathrm{~min}$.

$\times 2000$

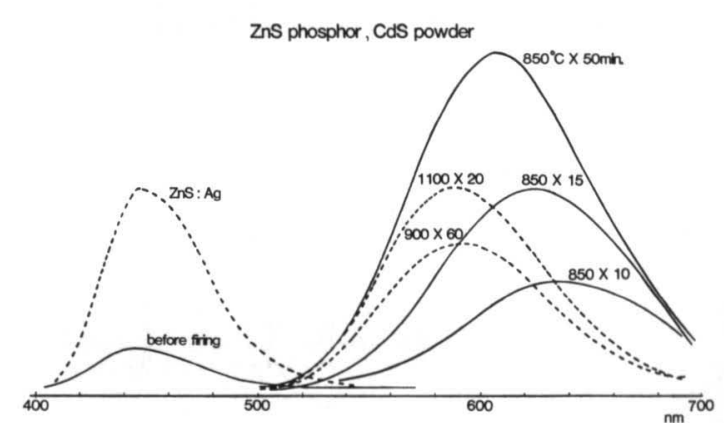

Fig. 7 The change of emission spectra. $850 \times 10$ means the firing at $850^{\circ} \mathrm{C}$ for $10 \mathrm{~min}$.. The coordinate of dotted curves is three times of that of solid ones. 


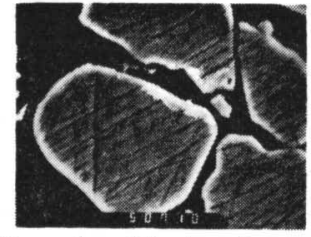

Secondary Electron Image

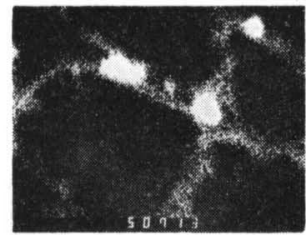

$\mathrm{ZnL} \alpha$

Photo. 4

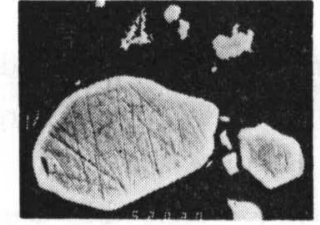

Secondary Electron Image

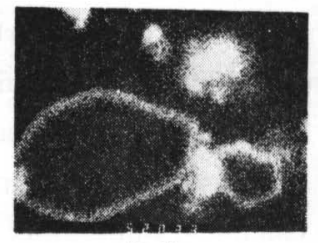

$\mathrm{ZnL} \alpha$

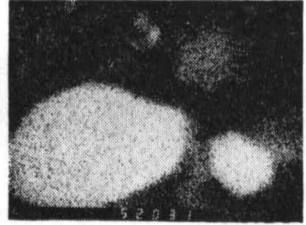

$\operatorname{CdL} \alpha$

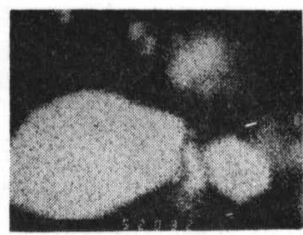

$\operatorname{SK} \alpha$

Photo. 5

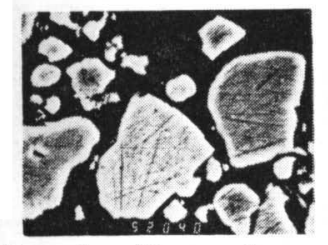

Secondary Electron Image

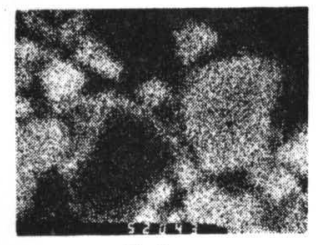

$\mathrm{ZnL} \alpha$

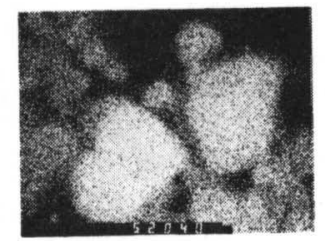

$\mathrm{CdL} \alpha$

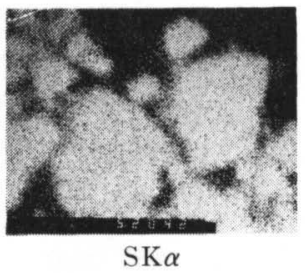

Photo. 4-6. EPMA Photograph. CdS crystal and $\mathrm{ZnS}$ powder. 4 は $850^{\circ} \mathrm{C} 10 \mathrm{~min}$. 5 は $850^{\circ} \mathrm{C} 30 \mathrm{~min}$. 6 は. $850^{\circ} \mathrm{C} 60 \mathrm{~min}$. $\times 2000$

Photo. 6

cadmium sulfide as the sublimation temperature of cadmium sulfide is lower than that of zinc sulfide. Especially, when cadmium has a form of fine powder, the amount of sublimation would be larger than the case of large crystal.

The results shown in Fig. 7 and Table 1 support the explanation described above. It is well known that ultraviolet light penetrates into zinc or cadmium sulfide till the depth of $0.2 \mu$, therefore the emission under ultraviolet excitation is caused by the electronic process in the neighbourhood of sulfide surface. By heating the mixture of cadmium sulfide powder and zinc sulfide phosphors whose emission has a peak at $440 \mathrm{~nm}$, the emission peak changed suddenly to $650 \mathrm{~nm}$, which corresponds the peak wavelength of CdS : Ag emission. This result would be explained by the fact that cadmium sulfide covers the outer surface of zinc sulfide phosphors as clarified in Fig. 4 and Photos. 1-3. Meanwhile it is explicit that silver begins to diffuse at the temperature as low as $300^{\circ} \mathrm{C}$. By continuing to heat the phosphor at $850^{\circ} \mathrm{C}$ zinc diffuses into cadmium sulfide layer to shift the spectral distribution of emission to the short wavelength. When cadmium sulfide phosphors are used as a starting materials, the amount of sublimation decreases and the shift of emission peak is not so large as the case of cadmium sulfide powder, as shown in Table 1 .

\section{Conclusion}

The simplest one of the solid state reactions which start from two or more phases would be the 
formation of solid solution and this formation in the ZnS-CdS system have been kinetically analysed.

It was found by $X$-ray diffraction method that values of activation energy obtained from the height decrease of diffraction lines $\mathrm{ZnS}(102)$ are $35 \mathrm{kcal} / \mathrm{mol}$ for $\mathrm{ZnS}: \mathrm{CdS}=1: 1$, and $41 \mathrm{kcal} / \mathrm{mol}$ for $7: 3$. These values are a little smaller than $\mathrm{NaCl}-\mathrm{KCl}$ or $\mathrm{CaO}-\mathrm{SrO}$ system.

The formation process was observed by using the zinc sulfide or cadmium sulfide phosphor as one of the starting materials. It was found by EPMA and the observation of emission spectra that cadmium sulfide covers the outer surface in early stage of solid solution formation. It was assumed that cadmium sulfide would sublimate on the first stage of the formation especially when cadmium sulfide was fine powder. Thereafter the mutual diffusion proceeded to form solid solution.

Acknozeledgement: The authors express their thanks for the cooperation of experiments to $\mathrm{Mr}$. Tadao Sekine in National Chemical Laboratory for Industry.

\section{Reference}

1) M. Yonemura and Y. Kotera: Nippin Kagaku Kaishi, (1981), 1462.

2) Y. Kotera, Y. Segawa and M. Yonemura: Presented at spring meeting of the Society (May 1982, Tokyo)

3) J. A. Hedvall: "Einführung in die Festkörperchemie", Vieweg (1952).

4) Y. Kotera, T. Sekine and Z. Naturforschung: 24a, (1969), 1408.

5) H. Kawai, T. Abe and T. Hoshina: Jpn. J. Appl. Phys., 20 (1981), 313.

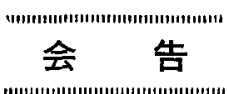

\section{基礎講座 “これからの生産技術”}

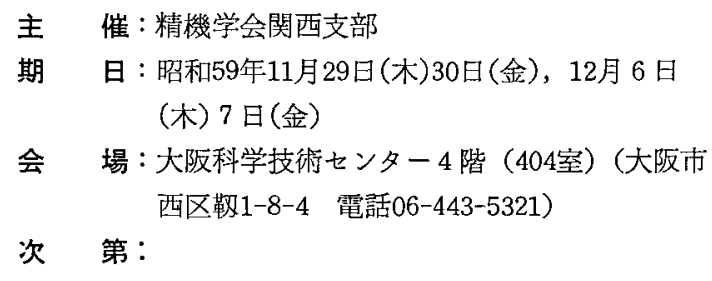

\section{1月29日（木） $9: 00 \sim 16: 40$}
1. 開会の辞
岩田一明
2. 材科学の基礎 （大阪大・工）山田 朝治
3. 加工のための材科学
(大阪大・工）川辺 秀昭
4. 風体の表面之検查法
（神戸大 $\cdot 工 ）$ 金持 徹
5. 新しい表面の制御法
（大阪大・工）梅野 正隆

11月30日 (金) $9: 00 \sim 16: 30$

6. 精密塑性加工 (大阪府大.工) 朝倉 健二

7. 精密機械加工と加工面（大阪大・工）井川 值哉

8. 超精密加工 (大阪大・工) 森勇蔵

9. 電気加工とその特質 (大阪大・工) 木本 康雄

12月 6 日(木) $9: 00 \sim 16: 30$

10. 工作機械の要素技術（新日本工機侏）東本 暁美
11. 工作機械の動剛性と振動

12. 工作精度に及ぼす熱の影響

（神戸大・工）森脇 俊道

（京都大・工）垣野 義昭

13. 加工ふん囲気 （大阪大・工）玉村謙太郎

12月 7日(金) 9:00〜 16:40

14. 計測制御系におりるセンサー

（神戸大・工）松本 治弥

15. マイクロコンピュータの計测への忘用

（大阪府大・工）川口 格

16. 生産のシステム化（神戸大・工）岩田一明

17. 生産におりる経済性（大阪府大・工）橋本 文雄

18. 閉会の辞広松良男

定 員：90名, 先着順により満員になり次第縍切りま す.

加 費：会員（協賛団体・会員を含む） $=40,000$ 円 非会員 $=50,000$ 円，学生会員 $=15,000$ 円. 小 ずれす筫料 1 冊代金含む

申込締切：昭和59年11月 20 日（火）

申 込 先: 精譏学会関西支部 565 吹田市山田区2-1 大阪大学工学部精密工学科内 電話 06-8775111 